\title{
A Detailed Analysis over Some Important Issues towards Using Computer Technology into the EFL Classrooms
}

\author{
Abbas Pourhosein Gilakjani \\ Lahijan Branch, Islamic Azad University, Lahijan, Iran \\ *Corresponding Author: s_m_a57@yahoo.com
}

Copyright (C) 2014 Horizon Research Publishing All rights reserved.

\begin{abstract}
Computer technology has changed the ways we work, learn, interact and spend our leisure time. Computer technology has changed every aspect of our daily life- - how and where we get our news, how we order goods and services, and how we communicate. This study investigates some of the significant issues concerning the use of computer technology resources in the EFL classrooms. The first aim of the study is to discuss the advantages of the use of computer technology into the classroom. The second aim is to explain the successful integration of computer technology into the classroom. The third aim is to elaborate teachers' roles in computer technology integration. The last aim is to mention contribution of computer technology to English Language Teaching and learning. The review of the related literature shows that simply introducing computer technology resources does not guarantee teachers' use of these in practice. Knowledge of EFL teachers' roles about teaching, learning and computers affords them the opportunity to design and implement EFL instruction.
\end{abstract}

Keywords Advantages, Integration, Roles, Contribution

\section{Introduction}

According to Bennett, Culp, Honey, Tally and Spielvogel [1], it is expected that computer technology should help lead the way to improve teaching and learning in the classrooms. Computer technology should be a tool to help teachers meet the educational needs of their learners. Computer technology cannot function as solutions in isolation but must be thought of as key ingredients in making it possible to address core educational challenges.

Bajcsy [2] said that computer technology can serve as an enabler in teaching and learning to help organize and provide structure for material to students, help students and teachers interact anytime and anywhere and facilitate and assist in the authentication and prioritization of Internet material, simulate, visualize, and interact with scientific structures, processes, and models and help in learning history and depicting future trends.
Wilson [3] stated that computer technology as offering endless possibilities to enhance educational experiences, expand academic opportunities and develop critical employment skills. Thompson, Schmidt and Stewart [4] emphasized that the real promise of computer technology to be in its potential to facilitate fundamental changes in the nature of teaching and learning.

Bransford, Brown and Cocking [5] and Roschelle, Pea, Hoadley, Gordin and Means [6] said that the interactivity of computer technologies is cited as a key feature that enables students to receive feedback on their performance, test and reflect on their ideas and revise their understanding. Computer technology can enable teachers and students to build local and global communities that connect them with interested people and expand opportunities for learning. Bransford, Brown and Cocking [5] stated that the positive impact of computer technology does not come automatically; much depends on how teachers use it in their classes.

Means, Penuel and Padilla [7] showed that some teachers use computer technology to change pedagogy and curriculum. Instead of dispensing knowledge, teachers set up projects, arrange for access to appropriate resources and create organizational structures and support that can help students succeed. These approaches move the concept of learning beyond the rote memorization of facts and procedures toward learning as a process of knowledge creation.

In this paper, the researcher discusses the advantages of the use of computer technology into the classroom, explains the successful integration of computer technology into the classroom, elaborate teachers' roles in computer technology integration and reviews contribution of computer technology to English Language Teaching and learning.

\section{Advantages of the Use of Computer Technology into the Classroom}

Some studies have been done by researchers to understand whether the use of computer technology into the classrooms assists students or not [8]. Individual factors like the impacts of particular software use with reading and mathematics 
curriculum have been examined by these researchers while other researchers concentrate on the effect of installing and utilizing computer-based technology in the classrooms.

Researchers' interest on the influences of computer technology on education has been increasing in the last years and this will give the teachers an opportunity to discover these new innovations and use them for their pedagogical methods. One of the most important findings toward using computer technologies is that they change the way teachers and students teach and learn their language [8].

A learning atmosphere centered around the student rather than the teacher will create positive changes. The reason is that the use of computers as learning tools can bring about better results than the traditional methods. Through using computer technology, the classroom becomes an active place full of meaningful activities where the students are made responsible for their own learning [8].

Meaningful activities like problem-based learning projects, using Internet to search for information for a report, or the preparation of presentation assignments can be provided for students. By using software and hardware as instructional tools, students can create a product to be presented to teachers so that they may review and learn collaboratively [8].

Students' interest and motivation towards the subject can be increased by the mentioned factors and these persuade students to become independent researchers. The teachers take the role of facilitators who guide students to an obtainable aim. Teachers cooperate with their students and this will automatically enhance critical thinking skills and the use of computer technology in them [9].

The increase of cooperation among teachers and students is the other positive and desirable effect of using computer technology into the classroom. This cooperation can be seen through the frequent trading of computer skills, shared advices about computer technology and the role of the students as teachers [10].

Students' self-confidence will be enhanced if we permit them to become assistants in the instruction process. They should be provided with enough opportunity to strengthen their opinions and skills already learned. Students will be able to aid teachers on using computer technology because they have had enough time to learn while teachers work on directing the instruction [10]. This will also increase the learner's opportunity to use computer technology meaningfully and collaboratively.

The use of computer technology in the classroom shows a true learning experience that increases the responsibilities of students. Computer technologies urge students to learn individually and to acquire responsible behaviors [9]. That is to say, there is no necessary for students to depend on their teachers to tell new sources of information but they can use these technologies to place their projects on a place that are available for them. The independent use of the computer technologies gives the students self-direction.

The other advantage of using computer technology is that students' motivation can be increased. Students who have laptops in classrooms are more enthusiastic about using computer technology and find learning environment more enjoyable than students who do not have laptops. These students show more interest and eagerness towards learning and indicate increased academic engagement. Students' motivation will lead them to important activities like different types of written expressions, multimedia products and the data analysis. These motivated students will have a feeling of pride and power than unmotivated students [10].

So far all the advantages of using computer were related to student achievement on subject areas and evaluations. How do students in computer-based classrooms do and score on tests? Students can have more achievement in all subject areas, when they engaged in technology-immersed classrooms [7].

According to O'Dwyer, Russell, Bebell, and Tucker-Seeley [11], students who edited their papers through the use of computer technology probably got higher English and language arts test scores and obtained higher writing scores. An extensive study was done on 21 schools by Shapely, Maloney and Caranikas-Walker [12]. The aim of this study was to evaluate the computer technology immersion in these middle schools and the related impacts on test scores and data collection lasted for four years. Test scores were related to the use of computer technology in the classroom but the result was positive only in schools where the immersion program was carefully done.

Test depended on the actual implementation of the program. Students got higher test scores in schools where implemented the program. Based on the obtained result, it was concluded that the greatest advantage was drawn on the positive attitude towards the use of computer technology in the classroom [12].

Achievement depends on the use of computer technology on the part of the student but computer technology alone cannot justify low scores. A study was done by Means [7] to understand what elements of computer technology use in the classroom really influence student scores. The study involved thirteen schools that had adopted reading and mathematics software to complete their program.

Seven schools could obtain high scores in both reading and mathematics, while the other six scored poorly [7]. According to the obtained findings, the software itself was not responsible for higher or lower achievement. Rather, components like a stable instructional understanding, main technical support and teachers' cooperation were necessary for obtaining learning experience and high test scores [7].

\section{Successful Integration of Computer Technology into the Classroom}

Gorder [13] stated that successful computer technology integration depends on the changes seen in a classroom. Computer technology integration is not an easy task and it includes the teacher who learns the computer technology and uses it in teaching and learning so that student learning is 
increased.

There are many factors that affect computer technology integration. Six factors have been shown by Hew [14] and they impact successful computer technology integration. They are lack of resources, lack of particular knowledge and skills, institutional structures, teachers' attitudes and beliefs toward computer technology and types of evaluation and subject culture.

Over the last years, there have been a lot of changes in computer technologies and it is very difficult for schools and universities to stay in step with the current computer technologies. Computers that were the best ones in the last years are now outdated. Updating computer resources is very expensive and there are not enough budgets for schools and universities to update them. So many institutions lack new technological materials and resources [14].

The other factor that is actually important for teachers is the lack of time. Teachers do not have enough time for preparation of computer technology while their responsibilities are increasing. Teachers need more time to prepare themselves and are needed to be on-site to provide technical support in order to have fast and sufficient responses when computers fail [14].

In order to use computer-based technologies effectively for their instruction, teachers should have particular technological knowledge and skills. Just focusing on how to do a particular program is not enough and there should be guidance in how to use it to enhance student learning. Classroom management should also be emphasized because it is related to the use of computer technologies [14].

According to Hew [14], institutional factors like lack of planning on the part of the administrators can prevent computer technology integration. There was a certain administrator who proudly announced at a staff meeting that the school had recently bought two computers that should be used for classrooms. But he did not talk about who will train the teachers on how to use them effectively.

Another factor for the successful computer technology integration is teacher attitudes and beliefs. The advantages of computer technology integration should be recognized to teachers. If a teacher thinks that the use of computer technology is a waste of time, he/she will use it that way. If teachers are aware of the benefits of integrating computer technology in increasing student learning they will find better ways to use it in their classrooms [14].

The other factor in the successful integration of computer technology is the pressure of high stakes testing [14]. While teachers have the responsibilities of assessments and data collection, they do not have sufficient time to explore and integrate new computer technologies. High stakes testing has changed the attention from applying computer-based technologies in teaching to applying computer-based assessments for the collection of student data.

Subject culture is the last factor that affects the use of computer technology. It is the rules and activities that have been created around a particular institution subject. If the subject teachers teach is not based on their computer-based technologies, they will not integrate computer technology. They need to be shown true examples of how computer technologies can work within the framework of teachers' job [14].

What can schools and universities do in order to integrate computer technology successfully? There are some useful suggestions. Institutions' administrators and teachers should work together to implement a computer technology plan that pay attention to integration strategies along with purchasing decisions. In order to assure students' learning and the change of beliefs and attitudes of teachers who are not familiar with the advantages of computer technologies, professional development should be really considered [14].

There should be a relationship between the computer technology plan and the curriculum standards. Teachers should know what instructional methods are the most effective when computer technologies are integrated in the classroom [14]. To test the effectiveness and efficiency of computer technologies, four instructional approaches were compared by Eysink et al., [15]. They involve hypermedia learning (Tell Me), observational learning (Show Me), self-explanation-based learning (Let $\mathrm{Me}$ Explain) and inquiry learning (Let Me Investigate).

Hypermedia learning (Tell Me) is computer-based learning that can be used interactively. Learners can choose what they would like to understand. High level of interactivity is the important feature of this software. The disadvantage is that sometimes students have difficulty to decide which content to focus and in what order they should work. Based on the researchers' findings, it was concluded that this software is very effective because it takes less time but is not as useful as the other instructional methods [15].

The second one is observational learning (Show Me) and it is a computer-based learning environment where a computer specialist shows and explains the task or procedure while the learner sees and does the task being indicated. This is a useful software because the computer specialist elaborates the reasons behind the procedure. The computer specialist can be a person in the room or a person on the computer screen. The learner is a passive person in the process and this type of instruction is effective but not as effective as hypermedia learning [15].

The third one is self-explanation-based learning and a number of worked out examples are indicated gradually and learners are given problems to solve utilizing the previous examples. This type of computer-based instruction is the most effective because learners concentrate on understanding the process and self-explain it to themselves. This type of learning is the least efficient since it is very time-consuming. This type of integration is suitable for particular subjects like math, science and art [15].

In the inquiry learning, learners should develop a hypothesis, do experiments and draw conclusions in order to confirm or disprove the original hypotheses. Deep understanding of the subject matter is the result of this type of learning. Developing a hypothesis and drawing conclusions are the learners' problems. This type of 
integration is suitable for scientific purposes and it is effective but not as effective as self-explanation-based learning. It is also time consuming [15].

What do we learn by analyzing the results? The most effective methods are the ones where the learners construct segments of the subject matter and the least effective ones are the ones where the subject matter is fundamentally offered to the learner [15]. The four instructional strategies can be used based on the age group, the concept(s) being presented, the learning goal(s) and time constraints. In order to integrate computer technology successfully and effectively, teachers should be trained to incorporate all four instructional approaches.

\section{Teachers' Roles in Computer Technology Integration}

According to Ferguson [16] and Grant [17], teachers are the main agents of implementing computer technology. If their roles are not considered in implementing computer technology, it will bring about only limited impacts. Without the participation of teachers, computer technology itself does not make a significant effect on students' achievement. The quality of education can be determined by teachers $[18,19]$.

Teachers should take new roles to help students follow their own research, use all kinds of computer technologies to collect, arrange, explain information and become thoughtful about information quality and sources [20].

Teachers' roles have been divided into five categories: planner, manager, facilitator, guide and participant in computer technology use [21]. As a planner, the teacher makes certain that computers are truly included into the program, organizes the learning environment and urges students to work together. As a manager, the teacher makes certain that students have similar access to computer technology and they use suitable programs based on the students' ability and particular needs.

As a facilitator, the teacher helps students to construct their own knowledge, helps them set their aims for learning and encourages them to examine carefully what they learn. As a guide, the teacher urges students for new learning and persuades students to take part in activities that raise their higher order thinking skills [21].

As a participant, the teacher cooperates with the students to do cognitive learning activities. These categories of teachers' roles imply that integrating computer technology into the classroom changes the teacher's traditional role from a giver of information to a facilitator of information [21].

According to Sianjina [22], a variety of teaching activities should be used by teachers in their classrooms and computer technology should be used as far as possible. Computer technology can be used not only as an information management tool, but also as a means of getting various backgrounds.

Schwarz [23] stated that use of computer technology can help teachers communicate with their students, use new techniques to curriculum and use new methods in teaching skills. Appropriate use of computer technology is only one aspect of teaching that allows teachers to evaluate choices for presentation of content and to monitor and measure students' understanding of content.

The purpose of using computer technology is to increase the learning process. A study was done by Iding, Crosby and Speitel [24]. In this study, teachers who used computers for their own personal use were very good at computers and had access to computers at schools and in individual classrooms and were interested in learning more about using computer technology for instructional and educational purposes.

Teachers were not aware of the importance of the educational software that could help them teach effectively and a lot of them did not utilize computer technology in teaching tasks such as student portfolios, demonstrations and simulations and student cooperation into the classes [24].

According to Whetstone and Carr-Chellman [25], computers were very important to education and teachers did not pay attention to the importance of their own pedagogical roles in implementing computers in classrooms. They did not have enough motivation toward computers in spite of the fact that they knew the importance of computer technology in changing schools.

Koehler and Mishra [26] stated that teachers can play a significant role in shaping classroom uses because education is one of the aspects of classroom uses consisted of the interaction of many information structure rather than a single simple structure. According to Mishra and Koehler [27], education needs teachers who can present different information structures in different conditions.

Shulman [28] offered a framework called Pedagogical Content Knowledge that evaluates the teachers' ability to use their knowledge and skills in a classroom where there is a changing structure. Profound field knowledge and pedagogy knowledge are needed for this model in order to present content at hand effectively.

One of the most important skills that teachers should have is the knowledge of computer technology use [29]. Many studies have been done towards what teachers should know about computer technology for effective education (Koehler et al., [30]. The way the computer technology is used in education in relation to the content and the effectiveness of its application is more important than computer technology itself is used [31].

The central issue towards the relationship between computer technology and education is under which conditions computer technology utilized in the classroom can enhance students' learning. Effective computer technology integration should provide education for all students [32].

Teachers should integrate computer technology into their teaching programs and use it to help students' self-development [33]. The knowledge structures that should be available to teachers for computer technology integration should be valuable. Unfortunately, teachers do not have sufficient knowledge and lack competence in integrating 
computer technology into their classroom teaching [34].

There are different views concerning the role of teacher in relation to computer technology integration. This is the duty of teachers to provide an appropriate learning environment for students who have different experiences, features and skills [35]. Teachers should be able to use computer technology effectively in the learning process and they should be a pattern for their students in using the computer technology.

According to Prensky [36], students are defined as natives of the digital world, while teachers are defined as immigrants of the digital world. In order for the immigrants of the digital world (teachers) to have a good connection with the natives (students), they should make changes in their teaching and the subjects they teach.

According to Akıncı and Seferoglu [37], principles of computer technology integration are computer technology, planning, application and evaluation. There are four basic aspects for a teacher's knowledge and ability to use computer technology appropriately. The knowledge of all four aspects depends on integrating computer technology in an educational environment. They are as follows:

1. Teachers should have technical knowledge of computer technology: Teachers should understand the technical knowledge of computer technology and know how to use it appropriately and effectively. Teachers should know how to solve technical problems that happen pertinent to that technology. A teacher also should have a basic understanding of the language and terms utilized in the application.

2. Teachers should be aware of the opportunities provided by computer technology. One of the basic reasons for using computer technology is to omit the possible problems teachers faced with them. Teachers should know the opportunities provided by computer technology to use it effectively [37].

In the past, students should attend classrooms to follow their lessons. Through using a smart board, a teacher can save what is written on the board and record his voice. This means that students who couldn't attend their lessons can have access to the information presented in the lessons [37].

3. Teachers should know the limitations of computer technology. Teachers should be aware of the limitations and opportunities of computer technology. Computer technology is brought to class environment by only considering its opportunities and limitations. One of the limitations of computer technology is the lack of enough light in the classroom when using overhead projection and this results in a decrease in the students' attention. This does not mean that computer technology should not be used and teachers should know what should be done for settling these limitations [38].

4. Teachers should know the teaching of computer technology. Knowing the teaching method is an important part for the effective use of computer technology for particular students. Teacher should know which teaching methods are supported by computer technology [27]. If teachers do not know the kind of pedagogy that is integrated with computer technology, they will not be able to teach successfully [39].

A teacher who wants to assess his/her own students' performance using electronic portfolios or using e-mail, needs how to use the computer technology in the teaching process. This teacher should understand which computer technology is suitable to use through considering the level of the students he/she is teaching [40].

When teachers plan lessons by means of using computer technology, they should consider many factors. Type of role that computer technology plays in teachers' instructions should be determined by teachers. According to Hughes [41], there are three roles for the computer technology to facilitate instruction. They are as follows:

1. Computer technology can be used as a replacement: Computer technology can be used for the same objective and acquisition. That is, computer technology has different roles within the environment. For instance, a teacher who solves a math problem by using power point presentation instead of writing computer technology actually has a renovation role.

2. Computer technology can be used as an amplification: This means that computer technology can be used without changing the goal of the lesson. This will bring about speed and efficiency for completing certain tasks and does not permit persons to enter the uninteresting tasks. For instance, computers or calculators can easily do the calculations of certain arithmetic operations. That is an example for the use of computer technology at an amplification level.

3. Computer technology can be used as a transformation: Creative education opportunities for creative instruction facilities can be provided by this role and designs new activities and alter the way students process and find solutions to their problems. Using graphic program to do data analysis is an example for the change role of computer technology.

Teachers should find solutions for the possible problems that happen in the application process that is evaluated as putting the plan into practice. According to Özmantar and Bingölbali [42], there are three important matters in the application process that direct students' attention towards developing the language. They are as follows:

1. Students should be included in the process. Some students who have fear of using computer technology are left behind of those who have no such fear. Therefore, teachers should support and spend extra time with these students in order to complete their learning process and learn the target knowledge or skill.

2. Students should be given the true instructions: Before beginning the application, students should be given instructions. Students will not be able to understand the instructions given, if the process begins before presenting the material. For instance, many students will not understand the instructions, if the video is started and then the students are told what to do.

3. Students should take notes pertinent to computer technology: It is necessary for students to take notes on the possible problems that may happen in the use of computer 
technology in order to resolve them.

The stage of evaluation doesn't have any relation to the evaluation of the students. It is related to the receiving of feedbacks toward using computer technology. The material or computer technology that is focused on using reflective thinking is evaluated by teachers. In this stage, the teacher tries to find answers to questions like: "Did the computer technology I utilized help me in obtaining the aims which I had determined?", "Which aims can I use this computer technology for?" (Özmantar \& Bingölbali [42].

\section{Contribution of Computer Technology to English Language Teaching and Learning}

According to Apple Education Inc., [43], there are numerous benefits of computer technology when it is integrated into teaching and learning. These benefits are as follows:

1. Student achievement is supported by computer technology. Computer technology has important positive effects on student achievement in reading, literacy, mathematics and science when integrated into teaching appropriately.

2. Students are engaged in learning and content creation through using computer technology. Integration of computer technology into formal learning and engaging students to create and publish their own work causes higher levels of students' achievement.

3. Access to education, virtual communities and skills can be enhanced by computer technology. Schools and universities provide students with disadvantaged communities and only access to computing tools and the Internet.

4. Inclusion can be developed by computer technology. Solutions can be provided by computer technology that help schools and universities to create inclusive learning environments that all students can be engaged to learn without considering their abilities, disabilities or learning styles.

5. Dropouts can be prevented through using computer technology. Computer technology has been mentioned by the National Dropout Prevention Centre as one of 15 strategies that have the most positive effects on the high graduation rate.

6. Differentiated teaching can be facilitated by computer technology. Teachers can provide personalized and just-in-time instruction for their students by computer technology. These are particularly important when supporting underperforming students, English language learners and students with disabilities.

7. Learning and research in significant STEM fields can be empowered by computer technology. One of the important devices for inquiry-based learning, advanced research and collaboration in the Science, Technology, Engineering and Mathematics fields for higher education is computer technology.

8. Profession and technical education can be reinforced by computer technology. Opportunities are given to teachers by computer technology to prepare their students with new kinds of knowledge and skills.

9. The learning day can be extended by computer technology. Students' learning can be supported by access to computer technology.

10. Teachers' quality can be supported by computer technology. Teachers' quality can be improved by ongoing and job-embedded professional development. Online learning and access to web resources can be facilitated by computer technology.

11. Timely and innovative evaluations can be done by computer technology. The administration and test scores processes can be done by technology-based assessments and these technologies in turn answer the need for classroom-based assessments and enable teachers to provide real-time feedback for students.

Based on the above contribution, it is concluded that computer technology increases learners' progress and their motivation towards learning, enhances teachers' motivation towards teaching, provides an authentic environment for both teachers and learners to teach and learn appropriately, provides personalized teaching for teachers, offers learners various types of computer knowledge and skills, has more advantages than traditional methods, makes better the quality of teachers' teaching and meets both teachers' and learners' goals and needs.

\section{Conclusion}

The full potential of computer technology is only realized when it is used effectively and in ways that connect to the continuing curriculum of the classroom and support creativity and critical thinking. It is necessary for teachers to be knowledgeable about the range of suitable computer technology applications. Teachers have the responsibility to help learners understand how to use computer technology in safe ways. Teachers need to expose learners to appropriate, challenging, creative and collaborative uses of computer technology into the classrooms. Teachers should be convinced of the advantages of computer technology resources in improving teaching and learning. This suggests the need for effective guidance and support for teachers in integrating computer technology resources into language instruction through direct practical experience. Teachers can use computer technology in improving the quality and effectiveness of the instruction in their classrooms. They should be aware of the computer technology resources that can be effectively integrated into their curriculum. It is important to understand teachers' reasons for the use of computer technology and their roles about the value of computer technology in teaching and learning practices. While introducing computer technology resources to teachers, guidance and assistance should be provided on 
ways of integrating these resources into their instruction.

\section{Acknowledgements}

I thank Seyedeh Masoumeh Ahmadi, Alizadeh, and Babaee for their extensive and insightful discussions and comments on the paper.

\section{REFERENCES}

[1] Bennett, D., Culp, K. M., Honey, M., Tally, B., \& Spielvogel, B. (2000). It all depends: Strategies for designing technologies for educational change. Paper presented at the International Conference on Learning Technology, Philadelphia, PA.

[2] Bajcsy, R. (2002). Technology and learning. In Visions 2020: Transforming education and training through advanced technologies. Washington, DC: U.S. Department of Commerce.

[http://www.technology.gov/reports/TechPolicy/2020Vision s.pdf

[3] Wilson, J. I. (2002). A visit to the Springdale school system in 2012. In Visions 2020: Transforming education and training through advanced technologies. Washington, DC: U.S. Department of Commerce. http://www.technology.gov/repor ts/TechPolicy/2020Visions.pdf.

[4] Thompson, A. D., Schmidt, D. A., \& Stewart, E. B. (2000). Technology collaboration for simultaneous renewal in $\mathrm{K}-12$ schools and teacher education programs. In Council of Chief State School Officers, 2000 State Educational Technology Conference Papers . Washington, DC: Council of Chief State School Officers.

[5] Bransford, J., Brown, A., \& Cocking, R. (2000). How people learn: Brain,mind, experience, and school. Washington, DC: National Academic Press.

[6] Roschelle, J., Pea, R., Hoadley, C., Gordin, D., \& Means, B. (2000). Future of Children, 10(2), 76-101.

[7] Means, B. (2010). Technology and education change: Focus on student learning. Journal of Research on Technology in Education, 42(3), 285-307.

[8] Dawson, K., Cavanaugh, C., \& Ritzhaupt, A. (2008). Florida's EETT Leveraging Laptops Initiative and its impact on teaching practices. University of North Carolina at Wilmington, 41(2), 143-159.

[9] Drayton, B., Falk, J. K., Stroud, R., Hobbs, K., \& Hammerman, J. (2010). After installation: Ubiquitous computing and high school science in three experienced, high-technology schools. Journal of Technology, Learning, and Assessment, 9(3).

[10] Mouza, C. (2008). Learning with laptops: Implementation and outcomes in an urban, underprivileged school. Journal of Research on Technology in Education, 40(4), 447-472.

[11] O’Dwyer, L. M., Russell, M., Bebell, D., \& Tucker-Seeley, K. R. (2005). Examining the relationship between home and school computer use and students' English/language arts test scores. Journal of Technology, Learning, and Assessment, $3(3)$.

[12] Shapley, K. S., Maloney, C., \& Caranikas-Walker, F. (2010). Evaluating the implementation fidelity of technology immersion and its relationship with student achievement. Journal of Technology, Learning, and Assessment, 9(4), 1-2.

[13] Gorder, L. M. (2008). A study of teacher perceptions of instructional technology integration in the classroom. Delta PI Epsilon Journal, 2, 63-76.

[14] Hew, K. F. (2007). Integrating technology into k-12 teaching and learning: Current knowledge gaps and recommendations for future research. Educational Technology, Research and Development, 55, 223-252.

[15] Eysink, T. H. S., deJong, T., Berthold, K., Kolloffel, F., Opfermann, M., \& Wouters, P. (2009). Learner performance in multimedia learning arrangements: An analysis across instructional approaches. American Educational Research Journal, 46(4), 1106-1149.

[16] Ferguson, B. (1997). Educational technology: An extended literature review. Retrieved September, 19, 2012, from http://www.sdavjr.davis.k12.ut.us/ brian/research/exlitrev.ht $\mathrm{m}$.

[17] Grant, C. M. (1996). Professional development in a technological age: New definitions, old challenges, new resources. Retrieved November 20, 2012, from

[18] International Society for Technology in Education. (2001). Retrieved 5, 2012, from http://www.iste.org/standards/index.cfm

[19] Wenglinsky, H. (2001). Flunking ETS: How teaching matters. Education Matters, 1(2), 75-78. Princeton, NJ: Policy Information Centre. Educational Testing Service.

[20] National Council on the Accreditation of Teacher Education (1997). Technology and the new professional teacher: Preparing for the $21 \mathrm{st}$ century classroom. Retrieved September 15, 2011, from

http://www.ncate.org/accred/projects/tech/tech-21.htm

[21] Ryba, K., \& Anderson, B. (1990). Learning with computers: Effective teaching strategies. Euguen, OR: International Society for Technology in Education.

[22] Sianjina, R. R. (2000). Educational technology and the diverse classroom. Phi Delta Kappan, 37, 26-28.

[23] Schwarz, G. (2000). Renewing teaching through media literacy. Phi Delta Kappan, 37, 8-12.

[24] Iding, M. K., Crosby, M. E., \& Speitel, T. (2002). Teachers and technology: Beliefs and practices. International Journal of Instructional Media, 29(2), 153-170.

[25] Whetstone, L., \& Carr-Chellman, A. A. (2001). Preparing pre-service teachers to use technology: Survey results. Tech Trends, 45(4), 11-17.

[26] Koehler, M. J., Mishra, P. (2009). What is technological pedagogical content knowledge? Contemporary Issues Technol. Teach. Educ., 9(1), 60-70.

[27] Mishra, P., \& Koehler, M. J. (2006). Technological Pedagogical Content Knowledge: A Framework for Teacher Knowledge. Teach. Col. Rec., 108(6), 1017-1054. 
[28] Shulman, L. (1986). Those who understand: Knowledge growth in teaching. Educ. Res., 15(2).

[29] Anderson, T. (2008). Towards a Theory of Online Learning, In T. Anderson, (Ed.) Theory and Practice of Online Learning, 2nd ed., 45-74.

[30] Koehler, M. J., Mishra, P., \& Yahya, K. (2007). Tracing the development of teacher knowledge in a design seminar: Integrating content, pedagogy and technology. Comput. Educ., 49, 740-762.

[31] Earle, R. S. (2002). The Integration of Instructional Technology into Public Education: Promises and Challenges. Educ. Technol., 42(1), 5-13.

[32] Zhao, Y., Pugh, K., Sheldon, S., \& Byers, J. (2002). Conditions for classroom technology innovations. Teachers College Record, 104, 482-515.

[33] Kumar, N., Rose, R. C., \& D’Silva, J. L. (2008). Teachers' Readiness to Use Technology in the Classroom: An Empirical Study. Eur. J. Sci. Res., 21(4): 603-616.

[34] Bozkurt, A., Bindak, R., \& Demir, S. (2010). Efficient Use of Computer Mathematics Teachers Eligibility Qualifications, and they worked, Environments, IETC-2010, Istanbul, Turkey.

[35] MEB (2008). Teacher Qualifications. Ankara: State Books Directorate.

[36] Prensky, M. (2001). Digital Natives, Digital Immigrants. J. Horizon, 9(5).

[37] Akıncı, A., \& Seferoglu, S. S. (2010). Technology Policy, Corporate Vision Studies and Reflections on Education, 4th International Symposium of Computer and Instructional Technologies.
[38] Demir, S., Akkoc, H., Özmantar, M. F., \& Bingölbali, M. (2010). Integration of Technology Assessment of the programs developed in order, 4th International Symposium of Computer and Instructional Technologies.

[39] Harris, J. B., Mishra, P., \& Koehler, M. J. (2007). Teachers' technological pedagogical content knowledge: Curriculum-based technology integration reframed, Paper presented at the American Educational Research Association Conference, Chicago, IL.

[40] Çoklar, A. N., Kılıçer, K., \& Odaba, F. (2007). A Critical Look at the Use of Technology in Education: Teknopedagoji, The Proceedings of the 7th International Educational Technology Conference, 3-5 May, North Cyprus.

[41] Hughes, J. (2005). The role of teacher knowledge and learning experience in forming technology-integrated pedagogy. Journal of Technology and Teacher Education, 13(2) 277-302.

[42] Özmantar, M. F., \& Bingölbali, E. (2009). Event Design and Basic Design Principles. Bingölbali, E. and Özmantar, MF (Ed.) Primary Mathematical Challenges Encountered and Solutions, Pegem Academy, Ankara, Turkey. (Book Chapter, Ss. 313-348).

[43] Apple Education Inc. (2009). American Recovery and Reinvestment Act-Stimulus Opportunities for Integrating Technology with Educational Goals (whitepaper). Retrieved on 7/9/2011 from http://images.apple.com/education/docs/A pple-Education_StimulusWhite_Paper.pdf.

http://ra.terc.edu/publications/TERC_pubs/technfusion/prof_dev/prof_dev_frame.html 